\title{
Nanoemulsion-based delivery systems to improve functionality of lipophilic components
}

\section{Isabel Odriozola-Serrano, Gemma Oms-Oliu and Olga Martín-Belloso*}

Department of Food Technology, University of Lleida, Lleida, Spain

\section{Edited by:}

Lilia Ahrné, SIK - The Swedish

Institute for Food and Biotechnology,

Sweden

Reviewed by:

Diego Garcia-Gonzalo, Universidad de Zaragoza, Spain

Francisco Jose Barba, University of Valencia, Spain

\section{*Correspondence:}

Olga Martín-Belloso, Department of Food Technology, University of Lleida, Av. Alcalde Rovira Roure 191, Lleida

25198, Spain

e-mail:omartin@tecal.udl.es
The use of active lipophilic substances such as antimicrobials and health-related compounds in the food industry is still a challenge due to their poor water solubility and instability in food formulations. Nano-sized structures such as nanoemulsions of oil-in-water are regarded as useful tools with a great potential in the food sector to incorporate food ingredients. Reducing the size of the active compounds incorporated within a solution would increase the surface area per mass unit of nanoemulsions, thus enhancing solubility and stability in foods. In addition, the ability of the active lipids to penetrate across biological membranes is also enhanced, thus boosting their biological functionality. An overview of the most significant studies reporting data about the potential benefits of active lipid nanoemulsions over conventional emulsions is presented.

Keywords: nanoemulsions, lipophilic nanoparticles, functionality, essential oils, antimicrobials, bioactive compounds

\section{INTRODUCTION}

Nowadays, consumers are demanding safe and healthy food products being at the same time as natural as possible. Therefore, new trends in the food market are leading toward a more rational use of food ingredients, such as preservatives, minimizing the concentration of synthetic additives, or even replacing them with natural substances. Nanotechnology is bursting into the food sector with several applications since it offers new insights to develop safer and healthier foodstuffs. The use of nanoemulsion-based delivery systems, as a method to encapsulate active lipophilic ingredients dispersed in aqueous media, is emerging as a potential tool to design new food products. Nanoemulsions are defined as oil droplets, with particle sizes comprised between 10 and $100 \mathrm{~nm}$, dispersed in aqueous media (1). These systems have been thought to have several advantages over conventional emulsions as colloidal delivery systems due to their smaller particle size. Nanoemulsions seem to present optical transparency, enhanced functionality, and physical stability, which would make them very attractive for food products. The aim of this review article was to provide an insight into the use of nanoemulsions containing active lipophilic as a strategy to improve their functionality.

\section{NANOEMULSION FORMATION}

The formulation of nanoemulsions consists on mixing at least three components being oil and aqueous phases plus a stabilizer. The lipid phase of oil-in-water nanoemulsions generally acts as a carrier of lipophilic active compounds and is the dispersed phase in the continuous phase. Usually, the lipophilic active ingredients are solubilized in the oil phase prior to the formation of emulsions. The oil phase can be formulated with different non-polar compounds, such as triglycerides, mineral oils, or essential oils. On the other hand, the aqueous phase of food emulsions might contain a variety of water-soluble constituents, including minerals, acids, bases, flavors, preservatives, vitamins, sugars, surfactants, proteins, or polysaccharides (2). Besides the lipid and aqueous phases, the formulation of nanoemulsions requires the use of stabilizers such as emulsifiers and hydrocolloids to prevent the breakdown of the nanoemulsion structure once it is formed. Emulsifiers are surfaceactive amphiphilic molecules; thus, the lipophilic part has affinity for non-polar media and the hydrophilic part has affinity for polar media. They are able to adsorb at the oil-water interface of droplet surfaces during emulsification, thus protecting droplets against re-coalescence or aggregation (3). Hydrocolloids have been extensively used in food formulations for their thickening properties when incorporated into aqueous phase. Modifying the rheology of the aqueous phase not only changes the emulsions texture and mouth-feel but also minimizes the droplets movement in the fluid so retarding gravitational separation (creaming or sedimentation) of lipid particles (4). In general, lipid nanoparticles can be prepared using two different approaches: high-energy or low-energy devices. High-energy methods consist in applying high disruptive forces with mechanical devices, capable of causing the breakup of oil droplets and disperse them into the water phase. Lowenergy approaches rely on the spontaneous formation of tiny oil droplets within mixed oil-water-emulsifier systems when the solution or environmental conditions are altered, such as composition or temperature (5).

\section{FUNCTIONALITY OF LIPID NANOPARTICLES}

There are several lipophilic active ingredients used in food industry such as certain antimicrobials or bioactive compounds that present low water solubility and instability when incorporating them in food formulations with high water content.

\section{ANTIMICROBIALS}

The use of natural essential oils as antimicrobials is becoming more and more popular due to the consumers demand of food free from synthetic additives. Essential oils contain a complex mixture of 
non-volatile and volatile compounds produced by aromatic plants as secondary metabolites. In particular, the antimicrobial action of essential oils has been attributed to their phenolic compounds and their interaction with microbial cell membranes, causing the leakage of cytoplasmatic constituents and, therefore, the loss of cell viability (6). Moreover, other mechanisms may be involved in microbial inactivation by essential oils since they could interfere with membrane function, altering its electron transport, nutrient uptake, proteins, nucleic acid synthesis, and enzyme activity (7). However, the use of essential oils in foods still presents several limitations considering their low solubility in aqueous media, as well as their toxicological, organoleptical, and economical aspects when they are incorporated in high doses (6). Several recent research works report the formation of nanoemulsions containing essential oils as a strategy to improve their functionality (Table 1). Essential oils incorporated in nanoemulsions seem to penetrate faster in the microbial membranes due to the increased area per weight unit (8-11). This would allow reducing the concentration to achieve an equivalent or even greater bacterial effect over conventional emulsions. However, processing method to obtain essential oil nanoemulsions determine their antimicrobial activity. SalviaTrujillo et al. (11) reported that ultrasound processing diminished the antimicrobial potential of lemongrass oil-alginate nanoemulsions against Escherichia coli in comparison with microfluidized nanoemulsions.

\section{BIOACTIVE COMPOUNDS}

There are many lipophilic bioactive compounds that are susceptible to be incorporated in foods due to their health promoting properties. Carotenoids, omega-3 fatty acids, polyphenols, flavonoids, phytosterols, and tocopherols are the main lipophilic bioactive compounds used to fortify foods. The incorporation of highly hydrophobic bioactive compounds in food is a challenge not only due to their poor water solubility, fast oxidation, and low sensorial detection thresholds but also because of their low bioaccessibility after the digestion in the gastrointestinal tract. The size and composition of the droplets in nanoemulsions influences the rate and extent of lipid digestion, as well as the bioavailability of lipophilic active compounds. The rate of lipid digestion increases as the droplet size decreases, which has been attributed to the increase in surface area of lipid exposed to intestinal juices containing lipase $(12,13)$. In addition, several authors $(14,15)$ reported that the smaller the droplet size of nanoemulsions, the higher the bioaccessibility of bioactive compounds encapsulated. It is known that not all lipids and fats present the same behavior through the gastrointestinal tract, thus the type of oil used in the formation of nanoemulsions will directly influence their biological activity. In this sense, it has been reported that the in vitro digestion of nanoemulsions containing lipid carriers with a longer chain of fatty acids led to a higher bioaccesibility of lipophilic active compounds (16-18). The emulsifier type and concentration will impact the susceptibility of the lipid droplets to coalescence and break up within the gastrointestinal tract, thereby altering the total surface area of lipid exposed to lipase action and consequently the rate of lipid digestion and bioaccessibility $(19,20)$. The most significant research studies focused on describe the benefits of incorporating bioactive compounds in nanoemulsions are summarized in Table 2.

\section{FUTURE PROSPECTS}

Nanoemulsions constitute one of the most promising systems to improve solubility and functionality of lipophilic active food ingredients. However, the promising expectation arising from the recent publication data are based on few research papers. Therefore, there is a need for further studies including a wide range of active compounds loaded in nanoemulsions to elucidate the real benefits of nanoemulsions depending on the kind of lipid nanoparticle. Despite lipid nanoparticles show similar digestibility

Table 1 | Functionality of nanoemulsions containing natural essential oils

\begin{tabular}{|c|c|c|c|c|c|}
\hline Antimicrobial compounds & Concentration & Lipid carrier & Stabilizers & Functionality & Reference \\
\hline Thyme essential oil & $\begin{array}{l}250 \mathrm{~mL} / \mathrm{kg} \text { of } \\
\text { antimicrobials in } \\
\text { the lipid carrier }\end{array}$ & Corn oil & $\begin{array}{l}\text { Tween } 80 \\
\text { Sodium dodecyl } \\
\text { sulfate } \\
\text { Lauric arginate }\end{array}$ & $\begin{array}{l}\text { The combination of thyme oil and antimicrobial } \\
\text { surfactant had an antagonist impact on the overall } \\
\text { antimicrobial efficacy }\end{array}$ & $\begin{array}{l}\text { Ziani et al. } \\
\text { (8) }\end{array}$ \\
\hline $\begin{array}{l}\text { D-limonene and other } \\
\text { terpenes }\end{array}$ & $\begin{array}{l}50 \mathrm{mg} / \mathrm{kg} \text { of } \\
\text { antimicrobials in } \\
\text { the } \\
\text { nanoemulsions }\end{array}$ & $\begin{array}{l}\text { Sunflower } \\
\text { and palm oil }\end{array}$ & $\begin{array}{l}\text { Soy lecithin } \\
\text { Tween } 20 \\
\text { Glycerol } \\
\text { monooleate } \\
\text { Modified starch }\end{array}$ & $\begin{array}{l}\text { Low concentrations of the nanoencapsulated } \\
\text { terpenes delayed the microbial growth or } \\
\text { completely inactivated the microorganisms } \\
\text { without altering the organoleptic properties of } \\
\text { fruit juices }\end{array}$ & $\begin{array}{l}\text { Donsi et al. } \\
\text { (9) }\end{array}$ \\
\hline Peppermint essential oil & $\begin{array}{l}200 \mathrm{~mL} / \mathrm{kg} \text { of } \\
\text { antimicrobials in } \\
\text { the lipid carrier }\end{array}$ & $\begin{array}{l}\text { Medium } \\
\text { chain } \\
\text { triglyceride }\end{array}$ & Modified starch & $\begin{array}{l}\text { Nanoemulsions showed prolonged antibacterial } \\
\text { activity in comparison with non-encapsulated oil }\end{array}$ & $\begin{array}{l}\text { Liang et al. } \\
\text { (10) }\end{array}$ \\
\hline Lemongrass essential oil & $\begin{array}{l}100 \mathrm{~mL} / \mathrm{kg} \text { of } \\
\text { antimicrobials in } \\
\text { the lipid carrier }\end{array}$ & - & Tween 20 & $\begin{array}{l}\text { Nanoemulsions produced by microfluidization } \\
\text { showed a faster inactivation kinetics against } E \text {. } \\
\text { coli in comparison with sonicated nanoemulsions }\end{array}$ & $\begin{array}{l}\text { Salvia- } \\
\text { Trujillo et al. } \\
\text { (11) }\end{array}$ \\
\hline
\end{tabular}


Table 2 | Functionality of nanoemulsions containing bioactive compounds.

\begin{tabular}{|c|c|c|c|c|c|}
\hline Bioactive compounds & Concentration $^{\mathrm{a}}$ & Lipid carrier & Stabilizers & Functionality & Reference \\
\hline$\beta$-carotene & $5 \mathrm{mg} / \mathrm{kg}$ & $\begin{array}{l}\text { Corn oil, } \\
\text { medium chain } \\
\text { triacylglycerols, } \\
\text { or orange oil }\end{array}$ & Tween 20 & $\begin{array}{l}\beta \text {-carotene bioaccessibility decreased in the } \\
\text { following order: corn oil > medium chain } \\
\text { triacylglycerols }>\text { orange oil }\end{array}$ & $\begin{array}{l}\text { Qian et al. } \\
\text { (17) }\end{array}$ \\
\hline$\beta$-carotene & $3 \mathrm{mg} / \mathrm{kg}$ & $\begin{array}{l}\text { Medium chain } \\
\text { triglyceride }\end{array}$ & Modified starch & $\begin{array}{l}\beta \text {-carotene bioaccesibility improved significantly after } \\
\text { encapsulation in nanoemulsions }\end{array}$ & $\begin{array}{l}\text { Liang et al. } \\
\text { (15) }\end{array}$ \\
\hline$\beta$-carotene & $5 \mathrm{mg} / \mathrm{kg}$ & $\begin{array}{l}\text { Corn oil and } \\
\text { Miglyol } 812\end{array}$ & Tween 20 & $\begin{array}{l}\text { In low fat nanoemulsions }(1 \%) \text {, the bioaccessibility } \\
\text { of } \beta \text {-carotene increase with increasing the fatty acids } \\
\text { chain length }\end{array}$ & $\begin{array}{l}\text { Salvia-Trujillo } \\
\text { et al. (14) }\end{array}$ \\
\hline$\beta$-carotene & $5 \mathrm{mg} / \mathrm{kg}$ & Corn oil & Tween 20 & $\begin{array}{l}\beta \text {-carotene bioaccesibility decreased as the initial } \\
\text { droplet size increased }\end{array}$ & $\begin{array}{l}\text { Salvia-Trujillo } \\
\text { et al. (18) }\end{array}$ \\
\hline Vitamin E & $8 \mathrm{mg} / \mathrm{kg}$ & $\begin{array}{l}\text { Medium chain } \\
\text { triglyceride }\end{array}$ & Tween 80 & $\begin{array}{l}\text { Bioaccessibility of vitamin E encapsulated in } \\
\text { nanoemulsions was higher compared with } \\
\text { conventional emulsions }\end{array}$ & $\begin{array}{l}\text { Mayer et al. } \\
\text { (20) }\end{array}$ \\
\hline $\begin{array}{l}\text { Coenzyme Q10 } \\
\text { Heptadecanoic acid }\end{array}$ & $1 \mathrm{mg} / \mathrm{kg}$ & $\begin{array}{l}\text { Corn oil, Mineral } \\
\text { oil }\end{array}$ & Tween 80 & $\begin{array}{l}\text { Bioavailability of coenzyme Q10 and heptadecanoic } \\
\text { acid was the highest when they were encapsulated } \\
\text { in droplets with the smallest size }\end{array}$ & $\begin{array}{l}\text { Cho et al. } \\
\text { (13) }\end{array}$ \\
\hline Curcumin & $1.5 \mathrm{mg} / \mathrm{kg}$ & $\begin{array}{l}\text { Long, medium, } \\
\text { and short chain } \\
\text { triacylglycerols }\end{array}$ & $\beta$-lactoglobulin & $\begin{array}{l}\text { The higher the chain length of fatty acids, the higher } \\
\text { the bioaccessibility of curcumin }\end{array}$ & $\begin{array}{l}\text { Ahmed et al. } \\
\text { (16) }\end{array}$ \\
\hline Curcumin & $1 \mathrm{mg} / \mathrm{kg}$ & Corn oil & $\begin{array}{l}\text { Tween } 20 \text { or } \\
\text { Sodium dodecyl } \\
\text { sulfate }\end{array}$ & $\begin{array}{l}\text { Curcumin exhibited high bioavailability in the } \\
\text { presence of Tween } 20 \text { in comparison nanoemulsions } \\
\text { with dodecyltrimethylammonium bromide }\end{array}$ & $\begin{array}{l}\text { Pinheiro } \\
\text { et al. (19) }\end{array}$ \\
\hline
\end{tabular}

${ }^{a}$ Concentration of the bioactive compound in the lipid carrier.

pattern compared to conventionally emulsions, their toxicological safety cannot be certainly assured. The biological path of lipid nanoparticles once they entry in human gut should be described to assess tissue location and possible toxicity.

\section{ACKNOWLEDGMENTS}

This work was supported by the Interministerial Commission for Science and Technology (CICYT) of the Ministerio de Educación y Ciencia (Spain) through the Project ALI AGL2012-35635.

\section{REFERENCES}

1. Mason TG, Wilking JN, Meleson K, Chang CB, Gravers SM. Nanoemulsions: formation, structure, and physical properties. J Phys Condens Matter (2006) 18(41):R635-66. doi:10.1088/0953-8984/18/41/R01

2. McClements DJ. Edible nanoemulsions: fabrication, properties, and functional performance. Soft Matter (2011) 7:2297-316. doi:10.1039/c0sm00549e

3. Qian C, McClements D. Formation of nanoemulsions stabilized by model foodgrade emulsifiers using high-pressure homogenization: factors affecting size. Food Hydrocoll (2011) 25:1000-8. doi:10.1016/j.foodhyd.2010.09.017

4. McClements DJ. Food Emulsions. Principles, Practices and Techniques. 2nd ed. Boca Raton, FL: CRC Press (2005)

5. Anton N, Vandamme TF. The universality of low-energy nano-emulsification. Int J Pharm (2009) 377(1-2):142-7. doi:10.1016/j.ijpharm.2009.05.014

6. Burt S. Essential oils: their antibacterial properties and potential applications in foods - a review. Int J Food Microbiol (2004) 94(3):223-53. doi:10.1016/j. ijfoodmicro.2004.03.022
7. Bajpai VK, Baek KH, Kang SC. Control of Salmonella in foods by using essential oils: a review. Food Res Int (2011) 45:722-31. doi:10.1016/j.foodres.2011.04.052

8. Ziani K, Chang Y, McLandborough L, McClements DJ. Influence of surfactant charge on antimicrobial efficacy of surfactant-stabilized thyme oil nanoemulsions. J Agric Food Chem (2011) 59(11):6247-55. doi:10.1021/jf200450m

9. Donsi F, Annunziata M, Sessa M, Ferrari G. Nanoencapsulation of essential oils to enhance their antimicrobial activity in foods. LWT-Food Sci Technol (2011) 44(9):1908-14. doi:10.1016/j.lwt.2011.03.003

10. Liang R, Xu S, Shoemaker CF, Li Y, Zhong F, Huang Q. Physical and antimicrobial properties of peppermint oil nanoemulsions. J Agric Food Chem (2012) 60(30):7548-55. doi:10.1021/jf301129k

11. Salvia-Trujillo L, Rojas-Graü MA, Soliva-Fortuny R, Martín-Belloso O. Impact of microfluidization or ultrasound processing on the antimicrobial activity against Escherichia coli of lemongrass oil-loaded nanoemulsions. Food Control (2014) 37(1):292-7. doi:10.1016/j.foodcont.2013.09.015

12. McClements DJ, Li Y. Structures emulsions-based delivery systems: controlling the digestion and release of lipophilic food components. Adv Colloid Interface Sci (2010) 159(2):213-28. doi:10.1016/j.cis.2010.06.010

13. Cho HT, Salvia-Trujillo L, Kim J, Park Y, Xiao H, McClements DJ. Droplet size and composition of nutraceutical nanoemulsions influences bioavailability of long chain fatty acids and coenzyme Q10. Food Chem (2014) 156:117-22. doi:10.1016/j.foodchem.2014.01.084

14. Salvia-Trujillo L, Qian C, Martín-Belloso O, McClements DJ. Modulating $\beta$ carotene bioaccessibility by controlling oil composition and concentration in edible nanoemulsions. Food Chem (2013) 139(1-4):878-84. doi:10.1016/j. foodchem.2013.02.024

15. Liang R, Shoemaker CF, Yang X, Zhong F, Huang Q. Stability and bioaccessibility of $\beta$-carotene in nanoemulsions stabilized by modified starches. J Agric Food Chem (2013) 61:1249-57. doi:10.1021/jf303967f 
16. Ahmed K, Li Y, McClements DJ, Xiao H. Nanoemulsion- and emulsion-based delivery systems for curcumin: encapsulation and release properties. Food Chem (2012) 132(2):799-807. doi:10.1016/j.foodchem.2011.11.039

17. Qian C, Decker EA, Xiao H, McClements DJ. Nanoemulsion delivery systems: influence of carrier oil on $\beta$-carotene bioaccessibility. Food Chem (2012) 135(3):1440-7. doi:10.1016/j.foodchem.2012.06.047

18. Salvia-Trujillo L, Qian C, Martín-Belloso O, McClements DJ. Influence of particle size on lipid digestion and $\beta$-carotene bioaccessibility in emulsions and nanoemulsions. Food Chem (2013) 141(2):1472-80. doi:10.1016/j.foodchem. 2013.03.050

19. Pinheiro AC, Lad M, Silva HD, Coimbra MA, Boland M, Vicente AA. Unravelling the behaviour of curcumin nanoemulsions during in vitro digestion: effect of the surface charge. Soft Matter (2013) 9:3147-54. doi:10.1039/c3sm27527b

20. Mayer S, Weiss J, McClements DJ. Behavior of vitamin E acetate delivery systems under simulated gastrointestinal conditions: lipid digestion and bioaccessibility of low-energy nanoemulsions. J Colloid Interface Sci (2013) 404:215-22. doi:10.1016/j.jcis.2013.04.048
Conflict of Interest Statement: The authors declare that the research was conducted in the absence of any commercial or financial relationships that could be construed as a potential conflict of interest.

Received: 06 October 2014; accepted: 23 November 2014; published online: 05 December 2014.

Citation: Odriozola-Serrano I, Oms-Oliu G and Martín-Belloso O (2014) Nanoemulsion-based delivery systems to improve functionality of lipophilic components. Front. Nutr. 1:24. doi: 10.3389/fnut.2014.00024

This article was submitted to Nutrition and Food Science Technology, a section of the journal Frontiers in Nutrition.

Copyright (c) 2014 Odriozola-Serrano, Oms-Oliu and Martin-Belloso. This is an openaccess article distributed under the terms of the Creative Commons Attribution License (CC BY). The use, distribution or reproduction in other forums is permitted, provided the original author(s) or licensor are credited and that the original publication in this journal is cited, in accordance with accepted academic practice. No use, distribution or reproduction is permitted which does not comply with these terms. 